\title{
IMPLEMENTASI LMS MOODLE UNTUK E-LEARNING SD MUHAMMADIYAH MAESAN DAN SD MUHAMMADIYAH BANGERAN, YOGYAKARTA
}

\author{
Hanifah Rahmi Fajrin ${ }^{1}$, Sigit Widadi ${ }^{1}$, Arif Budi Raharja ${ }^{2}$ \\ 1Program Vokasi Universitas Muhammadiyah Yogyakarta, \\ 2Program Studi Pendidikan Agama Islam, Fakultas Agama Islam, Universitas Muhammadiyah \\ Yogyakarta \\ hanifah.fajrin@vokasi.umy.ac.id.
}

\begin{abstract}
Generally, schools in remote areas, for example, SD Muhammadiyah Maesan and SD Muhammadiyah Bangeran have few students. This could be due to several factors related to learning technology: teacher competence in using ICT devices for learning, elementary schools do not yet have software as a forum for digital learning content, ICT infrastructure in elementary schools is not sufficient for knowledge. Therefore, the community service team implemented a Moodle learning management system (LMS) platform for learning in both schools. This e-learning platform can make it easier for teachers or teaching staff to create IT / e learning-based teaching material content. The teachers are taught the process of installing, dressing, and maintaining the devices. After implementing community service, SD Muhammadiyah Maesan and SD Muhammadiyah Bangeran can use e-learning / moodle cloud in managing the subjects to be taught.
\end{abstract}

Keywords: LMS, IT, moodle, school

\begin{abstract}
Abstrak
Umumnya, untuk wilayah yang berada jauh dari perkotaan, dalam hal ini yaitu SD Muhammadiyah Maesan dan SD Muhammadiyah Bangeran memiliki sedikit peminat (siswa), hal ini bisa disebabkan oleh beberapa faktor yang berhubungan dengan teknologi pembelajaran, yaitu: Kompetensi tenaga pendidik menggunakan perangkat ICT untuk pembelajaran belum memadai, SD belum memiliki piranti lunak sebagai wadah konten pembelajaran digital yang dapat menjadi media interaksi kegiatan belajar mengajar antara guru dan siswa melalui internet, Infrastruktur ICT di SD belum mencukupi kebutuhan untuk pembelajaran. Oleh karena itu, tim pengabdian masyarakat mengimplementasikan suatu platform learning management system (LMS) Moodle Untuk ELearning pada kedua sekolah tersebut. Dengan adanya platform e learning ini dapat memudahkan para guru atau staff pengajar dalam mebuat konten bahan ajar berbasis IT/e learning. Para guru diajarkan proses instalasi, pamakaian dan perawatan piranti. Setelah pelaksanaan pengabdian masyarakat, SD Muhammadiyah Maesan dan SD Muhammadiyah Bangeran dapat menggunakan e-learning/moodle cloud dalam mengelolah mata pelajaran yang akan diajarkan,
\end{abstract}

Kata kunci: LMS, IT,moodle, sekolah 


\section{PENDAHULUAN}

Peningkatan dan pemerataan mutu pendidikan di sekolah telah dilakukan oleh pemerintah menggunakan berbagai strategi. Langkah yang ditempuh antara lain melaksanakan program pelatihan untuk meningkatkan kompetensi guru dan tenaga kependidikan, menyediakan infrastruktur penunjang kegiatan pembelajaran dan menyempurnakan kurikulum pendidikan. Pelaksanaan program yang bersifat strategis hingga saat ini belum menyasar semua sekolah yang berstatus negeri maupun swasta termasuk sekolah milik yayasan muhammadiyah. Sebagai contoh yaitu Program Peningkatan dan Pemerataan Mutu Pendidikan melalui Utilization ICT for Educational Quality Enhancement Program (ICT EQEP) yang dilaksanakan pada tahun 2010 hingga tahun 2012 oleh konsorsium Dinas Dikpora Propinsi DIY, Kementerian Pendidikan dan JICA Foundation [1]. Program tersebut diperuntukkan bagi 500 sekolah SD dan SMP di Propinsi DIY sebagai wujud pilot project peningkatan dan pemerataan mutu pendidikan di Indonesia dan hanya sebagian kecil dari sekolah muhammadiyah yang masuk dalam kriteria penerima program ICT EQEP. Sekolah yang tidak memiliki ketersediaan ruang dan lahan untuk penempatan fasilitas ICT, jumlah siswa sedikit dan rombongan belajar yang kecil, rendahnya kompetensi IT para guru dan kurangnya peranan aktif komite sekolah terhadap upaya pemenuhan sarana dan prasarana yang dibutuhkan adalah kriteria sekolah yang tidak memenuhi syarat sebagai penerima program ICT EQEP (Jati 2013).

Bagi sekolah yang menjadi sasaran program ICT EQEP, para guru mendapatkan berbagai pelatihan menyusun konten bahan ajar elektronik yang ditampung dalam aplikasi learning management system (LMS) dan setiap unit sekolah mendapatkan hibah perangkat teknologi untuk mengakses konten pembelajaran dari Balai Teknologi Komunikasi Pendidikan (BTKP) Yogyakarta melalui jaringan WAN ICT (Wibowo dan Akhlis 2015). Kondisi demikian dinilai sebagai penyebab kesenjangan fasilitas yang semakin dalam antara sekolah penerima hibah dan sekolah lain di sekitarnya yang tidak masuk dalam kriteria 500 sekolah pilot project (SaravankumarAR 2018).

SD Muhammadiyah Maesan dan merupakan dua sekolah yang berada di Kecamatan Lendah Kabupaten Kulon Progo pada cakupan wilayah Pimpinan Cabang Muhammadiyah Lendah (Admin 2018b). Kedua sekolah tersebut berjarak sekitar $25 \mathrm{~km}$ dari UMY. SD Muhammadiyah Maesan (Mitra I) didirikan berdasarkan SK tanggal 01 April 1927 dan berlokasi di Desa Wahyuharjo, Kecamatan Lendah Kabupaten Kulon Progo. Menempati lahan seluas $1164 \mathrm{~m} 2$ yang terdiri atas bangunan ruang kelas, ruang guru, perpustakaan, ruang sanitasi, tempat parkir sepeda siswa dan guru serta halaman sekolah. Sekolah ini belum memiliki laboratorium. Akses internet menggunakan modem Telkomsel Flash. SD ini memiliki 152 siswa yang terdiri dari 80 siswa laki-laki dan 72 siswa perempuan dengan 6 rombel, memiliki 8 guru dan menerapkan kurikulum tahun 2013 dan jam belajar sehari penuh selama lima hari sekolah per minggu. Sedangkan SD Muhammadiyah Bangeran (mitra II) hanya memiliki 29 siswa, terdiri dari 12 siswa laki-laki dan 17 siswa perempuan 
dengan 6 rombongan belajar dan memiliki 9 guru (Admin 2018a).

Berdasarkan kenyataan yang terjadi dari kedua mitra bahwa jumlah peserta didik yang relatif sedikit dibandingkan sekolah lain membuktikan bahwa minat masyarakat dalam mempercayakan pendidikan putra-putrinya di lembaga mitra cukup rendah disebabkan oleh permasalahan berikut ini:

1. Kompetensi tenaga pendidik menggunakan perangkat ICT untuk pembelajaran belum memadai. Pelatihan pemanfaatan ICT untuk pembelajaran memang belum menjangkau semua sekolah, termasuk di lembaga mitra sehingga para guru belum memiliki kemampuan yang setara dengan guru di sekolah lain yang pernah menjadi grantees pada program peningkatan mutu pembelajaran menggunakan ICT.

2. Lembaga mitra belum memiliki piranti lunak sebagai wadah konten pembelajaran digital yang dapat menjadi media interaksi kegiatan belajar mengajar antara guru dan siswa melalui internet. Walaupun LMS bukan lagi hal baru dalam dunia pendidikan, namun untuk para guru di lembaga mitra yang masih awam dengan pemanfaatan LMS. Namun proses instalasi dan konfigurasi sistem pada LMS memang bukan hal yang mudah bagi sebagian besar guru di lembaga mitra, sehingga perlu dibantu oleh para dosen yang bersedia melaksanakan pengabdian masyarakat dan punya kemampuan menyediakan hasil instalasi LMS yang sudah siap pakai.

3. Infrastruktur ICT di lembaga mitra belum mencukupi kebutuhan untuk pembelajaran. Dua lembaga mitra pengabdian masyarakat belum memiliki infrastruktur ICT yang mencukupi kebutuhan untuk mendukung proses pembelajaran. Pengadaan infrastruktur ICT memang merupakan beban berat bagi lembaga mitra, apalagi jika dikaitkan dengan biaya perawatan dan pemeliharaan serta sistem pengamanan dari aspek kelistrikan dan tindakan kriminalitas.

Berdasarkan identifikasi permasalahan yang ada di lembaga mitra, maka akan dilakukan tindakan sebagai salah satu alternatif solusi yang memungkinkan untuk dilaksanakan sesuai skema pengabdian masyarakat. Sesuai dengan hasil identifikasi maka solusi yang akan diambil adalah:

1. Untuk membantu penyelesaian masalah kompetensi tenaga pendidik menggunakan perangkat ICT untuk pembelajaran pada dua mitra di lingkungan PCM Lendah maka akan dilaksanakan pelatihan membuat materi ajar digital dengan bantuan narasumber yang kompeten dari UMY dan mengimplementasikan LMS dengan memanfaatkan beberapa fitur di dalamnya yang sesuai kebutuhan mitra.

2. Diberikan bantuan aplikasi LMS siap pakai sesuai kebutuhan yang diinstal di layanan hosting untuk memuat materi ajar digital yang dibuat oleh para guru di lembaga mitra. Bantuan ini meliputi kustomisasi LMS, sewa hosting dan sewa domain.

\section{METODE}

\section{Tempat Pelaksanaan Kegiatan}

Pengabdian masyarakat akan dilaksanakan di SD Muhammadiyah Maesan yang beralamat di Maesan II Wetan, Wahyuharjo, Lendah, Kulon Progo dan SD Muhammadiyah Bangeran yang berlokasi di Kabupaten Kab. Kulonprogo dengan alamat 
Bangeran, Bumirejo, Lendah, Profinsi DI Yogyakarta.

\section{Sasaran Kegiatan}

Khalayak sasaran dari kegiatan ini segenap pihak sekolah yaitu guru atau staff pengajar.

\section{Pelaksanaan Kegiatan}

Pelaksanaan pengabdian masyarakat dengan mitra dari PCM Lendah dengan dua sasaran mitra dua SD Muhammadiyah akan dilaksanakan dengan metode sebagai berikut:

a. Melakukan focus discussion group (FGD) untuk memperoleh gambaran lebih detil tentang permasalahan, potensi dan sumberdaya mitra sasaran. Langkah ini sekaligus untuk memperoleh kesepakatan jadwal detil pelaksanaan di lapangan agar program dapat dijalankan secara efektif dan efisien. Peserta terdiri dari para guru dan tenaga kependidikan lembaga mitra sasaran serta pengurus PCM sesuai bidang majelis.

b. Melakukan workshop pengenalan dan pembuatan materi ajar digital sesuai kurikulum yang dijalankan oleh mitra sasaran. Peserta terdiri dari para guru lembaga mitra sasaran. Narasumber dari dosen UMY yang kompeten di bidang elearning.

c. Melakukan sewa hosting dan domain serta instalasi dan kustomisasi LMS. Teknologi yang akan diimplementasikan meliputi piranti lunak aplikasi LMS dan internet. Aplikasi dan basis data LMS yang berbasis web akan diletakkan di Virtual Private Server. Guru, admin LMS dan siswa mengakses LMS menggunakan modem 3G/4G.
Admin memiliki tugas mengelola user dan fitur aplikasi. Guru memiliki tugas mengelola course, materi, tugas, ujian, kuis dan forum diskusi. Siswa memiliki hak akses materi dan mengerjakan soal ujian, kuis, tugas dan berpartisipasi dalam forum diskusi.

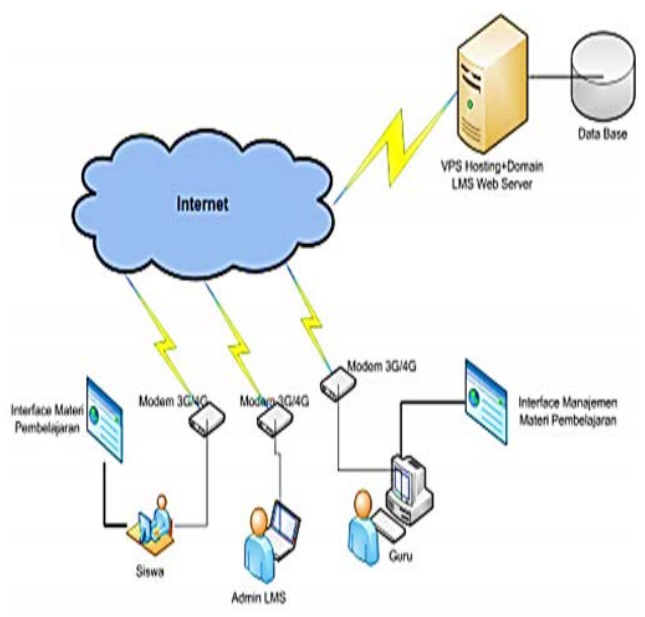

Gambar 1. Gambaran IPTEK LMS

d. Melakukan workshop pengunggahan dan ujicoba akses materi pembelajaran melalui LMS. Peserta para guru dan tenaga kependidikan dengan narasumber adalah dosen pengusul. Alat dan bahan yang digunakan dalam workshop sesi yaitu :

a) Aplikasi LMS MoodleCloud versi trial yang disediakan oleh moodlecloud.com

b) Materi LMS yang disusun oleh tim pelaksana pengabdian masyarakat

c) Laptop milik masing-masing peserta

d) Projector

e) Block Note, flashdisk dan alat tulis yang disediakan oleh tim 
pelaksana pengabdian masyarakat.

\section{HASIL DAN PEMBAHASAN}

Berikut ini rincian penjelasan kegiatan pelaksanaan pengabdian masyarakat:

1. Survey awal mencari lembaga pendidikan muhammadiyah berdasarkan penjelasan Pengurus Cabang Muhammadiyah Lendah untuk memperoleh data mitra yang potensial menjadi mitra kegiatan pengabdian masyarakat sesuai tema implementasi e-learning. Diperoleh informasi bahwa 2 sekolah yaitu SD Muhammadiyah Maesan dan SD Muhammadiyah Bangeran merupakan dua lembaga pendidikan milik muhammadiyah yang membutuhkan pendampingan implementasi dan pemanfaatan pembelajaran daring.

2. Survey lanjutan mengunjungi lokasi mitra yang direkomendasikan oleh pengurus cabang muhammadiyah Lendah, untuk memperoleh gambaran nyata mengenai kondisi dan situasi mitra dalam melaksanakan pembelajaran pada mas pandemi. Kegiatan ini juga untuk memperoleh gambaran tentang sumberdaya yang dimiliki oleh sekolah apabila menjadi mitra pengabdian masyarakat. Data sumberdaya yang berhasil diperoleh meliputi :

a. Jumlah siswa di kedua mitra perbedaannya sangat signifikan, SD Muhammadiyah Bangeran hanya memiliki siswa kurang dari 30 orang sedangkan siswa di SD Muhammadiyah Maesan berjumlah lebih dari 50 orang.

b. Fasilitas pembelajaran di kedua mitra memiliki kesenjangan cukup tinggi. SD Muhammadiyah Bangeran tidak memiliki fasilitas jaringan internet, projector yang layak digunakan serta ruang kelas yang kurang memadai dari aspek ukuran dan ketersediaan jaringan listrik di setiap kelas.

c. Lokasi kedua mitra memiliki nilai strategis yang sangat berbeda, SD Muhammadiyah Bangeran terletak di tengah pemukiman penduduk di tengah pedesaan yang berkontur lembah dan akses internet mobile yang tidak stabil. Sedangkan SD Muhammadiyah Maesan berada di tepi jalan raya yang menghubungkan kecamatan Galur dengan Kota Wates.

3. Koordinasi pelaksanaan dengan pihak mitra Kegiatan ini untuk memastikan pelaksanaan pengabdian masyarakat dapat berjalan lancar. Koordinasi meliputi lokasi, waktu dan peserta pengabdian masyarakat.

4. Workshop sesi I, dilaksanakan pada tanggal 23 Juli 2020 mulai jam 09.00 - 14.00 bertempat di SD Muhammadiyah Maesan. Peserta terdiri dari kepala sekolah dan para guru dari SD Muhammadiyah Maesan dan SD Muhammadiyah 
Bangeran sebanyak 20 peserta. Materi workshop meliputi :

a. Mengenal lingkungan LMS di moodlecloud.com

b. Membuat subdomain di situs moodlecloud.com

c. Seting tingkat dasar pada halaman LMS

d. Menambahkan user/pengguna LMS.

Kendala yang dihadapi selama pelatihan antara lain: istilah dalam modul LMS, keterampilan para guru menggunakan browser dan fasilitas di Ms Windows di komputer masing-masing, bandwidth internet yang kurang memadai untuk akses LMS secara bersamaan dan konversi struktur kurikulum berbasis tematik

5. Workshop II Kegiatan ini melanjutkan workshop sesi I yang didahului dengan mereview ketercapaian peserta dalam menggunakan LMS. Pelaksanaan workshop dimulai pada jam 08.00 dan diakhiri pada pukul 13.00 . Peserta yang hadir sejumlah 17 orang. Materi workshop meliputi:

a. Menambah kursus baru

b. Menambah aktifitas dan sumber daya

c. Mengatur peran pengguna yaitu peran pengguna sebagai guru dan sebagai siswa

d. Grading

6. Focus Discussion Group (FGD) Kegiatan ini sebagai penutup acara pengabdian masyarakat pada tanggal 29 Juli 2020, berlangsung pada jam 13.00 hingga jam 15.00 yang diarahkan pada diskusi tentang berbagai kemungkinan yang akan terjadi pada saat LMS diimplementasikan menggunakan LMS yang berbayar. Diskusi membahas pula tentang konsekuensi dari implementasi elearning menggunakan LMS yang harus dihadapi sekolah, pimpinan sekolah, guru, siswa dan orangtua serta masyarakat sekitar mitra dan diskusi tentang keselarasan RPP BDR terhadap implementasi LMS.

\section{SIMPULAN}

Setelah melaksanakan
pengabdian masyarakat di

\section{UCAPAN TERIMA KASIH}

Terima Kasih kepada LP3M UMY atas bantuan hibah pengabdian masyarakat 2019/2020.

\section{DAFTAR PUSTAKA}

Wibowo, T, I. Akhlis, And S. E. Nugroho. 2015. "Pengembangan Lms (Learning Management 
System) Berbasis Web Untuk Mengukur Pemahaman Konsep Dan Karakter Siswa.” Sci. J. Informatics 1(2): 127-37.

Admin. 2018a. "SD Muhammadiyah Bangeran.”

2018b. "SD Muhammadiyah Maesan.”

Http://Sekolah.Data.Kemdikbu d.Go.Id/Index.Php/Chome/Prof il/C05cc85c -2ef5-E011A0be- A35384e681a9 (December 31, 2019).

Jati, G. 2013. “Learning Management System (Moodle) and E-
Learning Content

Development." Sosioteknologi 12(28): 277-89.

Saravankumar-AR. 2018. "Role of ICT on Enhancing Quality of Education.” Int. J. Innov. Sci. Res. Technol 3(12): 717-19. 